\title{
Public Space for Street-Scape Theatrics. Guerrilla Spatial Tactics and Methods of Urban Hacking in Brisbane, Australia
}

\author{
Christopher Cox, Mirko Guaralda \\ Queensland University of Technology, Brisbane, Australia \\ Creative Industries Faculty, School of Design \\ christopher.cox@connect.qut.edu.au|m.guaralda@qut.edu.au
}

\begin{abstract}
It could be argued that architecture has an inherent social responsibility to enrich the urban and spatial environments for the city's occupants. However, how we define quality, and how 'places' can be designed to be fair and equitable, catering for individuals on a humanistic and psychological level, is often not clearly addressed. Lefebvre discusses the idea of the 'right to the city'; the belief that public space design should facilitate freedom of expression and incite a sense of spatial ownership for its occupants in public/commercial precincts. Lefebvre also points out the importance of sensory experience in the urban environment. "Street-scape theatrics" are performative activities that summarise these two concepts, advocating the 'right to the city' by way of art as well as providing sensual engagement for city users. Literature discusses the importance of Street-scape Theatrics however few sources attempt to discuss this topic in terms of how to design these spaces/places to enhance the city on both a sensory and political level. This research, grounded in political theory, investigates the case of street music, in particular busking, in the city of Brisbane, Australia. Street culture is a notion that already exists in Brisbane, but it is heavily controlled especially in central locations. This study discusses how sensory experience of the urban environment in Brisbane can be enriched through the design for busking; multiple case studies, interviews, observations and thematic mappings provide data to gather an understanding of how street performers see and understand the built form. Results are sometime surprisingly incongruous with general assumptions in regards to street artist as well as the established political and ideological framework, supporting the idea that the best and most effective way of urban hacking is working within the system. Ultimately, it was found that the Central Business District in Brisbane, Australia, could adopt certain political and design tactics which attempt to reconcile systematic quality control with freedom of expression into the public/commercial sphere, realism upheld. This can bridge the gap between the micro scale of the body and the macro of the political economy through freedom of expression, thus celebrating the idiosyncratic nature of the city.
\end{abstract}

Keywords: urban hacking; street performance; baskin; urban design; Brisbane.

\section{To cite this article:}

Cox, C.; Guaralda, M. (2016). Public Space for Street-Scape Theatrics. Guerrilla Spatial Tactics and Methods of Urban Hacking in Brisbane, Australia, The Journal of Public Space, I (I), I I 3-I 28, DOI: 10.5204/jps.vlil.I4

This article has been peer-reviewed and accepted for publication in The Journal of Public Space. Please see the Editorial Policies under the 'About' section of the journal website for further information.

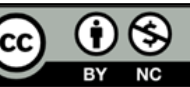

This work is licensed under a Creative Commons Attribution - Non Commercial 4.0 International License. https://creativecommons.org/licenses/by-nc/4.0/ 
Public Space for Street-Scape Theatrics.

Guerrilla Spatial Tactics and Methods of Urban Hacking in Brisbane, Australia

It could be argued that architecture has an inherent social responsibility to enrich the urban and spatial environments for the city's occupants (Deslandes, 20 I3; Jubany, 20I2), but how we define quality, and how 'places' can be designed to be fair and equitable, catering for individuals on a humanistic and psychological level is debated in the literature (Holt-Damant, Guaralda, Gomez, \& Miriam, 20I3), which often deals with these problems on a very analytical level. Public places are idealistically egalitarian and for all citizens in society, but as Orwell (1946) famously suggests, some are "more equal" than others. Architecture, as a politically informed profession of design, urban planning and placemaking, has the opportunity and the responsibility to consider public space with an egalitarian ethic. Certain failings in modernist architecture have demonstrated that humans need more than the mere fulfilment of their basic needs (Orom \& Cervone, 2009). This has been exemplified by Pruitt-Igoe, an infamous housing project which attempted to artificially contrive an environment for the low socio-economic class; once seen as a beacon of hope, the project was a tragic failure in terms of poverty, crime, suicide and segregation (Heathcott, 20I2).

This paper presents a pilot research grounded in the Lefebvrian idea of the "right to the city" and in the notion of idiosyncrasy, a structural or behavioural characteristic peculiar to an individual or group ("The American Heritage Dictionary of the English Language, Fourth Edition," 2009; Coleman, 2013); playfulness and idiosyncrasies transcend preconceived notions of governance, fear and pre-determination. They facilitate freedom of expression and incite a sense of spatial ownership; this will be defined as street-scape theatrics. Public spaces are a stage that demonstrates an intrinsic relationship between idiosyncratic environments and human engagement bringing about a sense of urban theatre. The street, an actor of public space, possesses an infinity of beautiful details, 'each so different from the other that one never encounters the same objects [...] one always finds something new' (Hays, 1998, p. II). This research has been designed to investigate, on a theoretical and practical level, to what extent architectural design can have a sympathy, or consideration, for the user on an idiosyncratic level through harnessing street-scape theatrics. The purpose of this research is to address the value of street expression in both an abstract and literal sense taking musical performances in Brisbane, Australia, as a case study to gather preliminary understanding on how public space identity can be enriched through unstructured activities like busking.

\section{Literature Review}

Public space design is inherently political because it attempts to find a platform for which a collective of individuals can exercise their right to be free (Mensch, 2007). But many spaces today are sterile, devoid of character, and are disjointed from the actual needs and desires of urban dwellers (Borden, $200 \mathrm{la}, 200 \mathrm{lb}$; Gehl, 20I0). Different theories are discussed in literature to deal with a civil and democratic approach to the design of urban environments (Hou, 20l0). Humanism, for example, seeks to establish the best possible life for the largest amount of people possible (Power, 2010). The concept of "greatest happiness for the greatest number" is also an underpinning belief of utilitarianism (Ralws, 1972: 22, cited in MacKenzie, 2009, 76). MacKenzie (2009) states that historically, justice and equality have been mutually exclusive. The fact that equality is now synonymous with 
justice is a modern concept and this has a deep impact in the way we consider contemporary public spaces (Harvey, 20I2). Ultimately MacKenzie highlights how the capitalist idea of satisfying the majority does not necessarily encompass the complex needs of all citizens. Pertaining to the seminal Orwellian text, Animal Farm, classes and different levels of "equality" are regarded as a prevalent human condition. The initial "seven commandments" or for arguments sake, ethical rules of society, are reduced down to a single phrase, 'All animals are equal, but some animals are more equal than others' (Orwell, 1946). As Wilkins (2007) contends architecture can marginalise certain sects of society or socio-economic class whilst "activist" forms of expression shape and sustain communities with regards to the ideologies formed, transmitted, and embedded into the built environment. However, as we see in the production of public space, inherent inequalities can exist based upon the lack of empathy for the user in the planning process. 'The view that planning is, above all else, a political activity [...] has only recently and grudgingly been accepted [...] this was because the professional ideology was essentially one that claims the planning was objective, technical, and as such not political' (Goldsmith, 1980: 126). There are certain behavioural sets involved in the analysis of planning policy. This can serve as a basis for generalization about the embedded political processes and their subsequent effect on planning policy (Torgovnik, 1990).

Gehl (1987) focuses his research on different types of activities within the urban realm and points out how social activities require suitable settings to foster interaction. The underpinning sociality of urban space creates a diversity of social roles and relationships, along with "institutional arrangements" that create social networks essential to efficient social order (Agiurre, 2007). Dangschat (2009) contends that a theory of space is needed by which it is possible to explain the inner logics of socio-spatial exclusion. This is with reference to the social inequalities that exist through respective power relations. Lefebvre (199I) offers some pivotal theories with regards to social space. He states that social space cannot be reduced to the "rank" of a simple object as it is the outcome of a sequence and set of operations. "Not a thing among other things, nor a product among other products: rather, it subsumes things produced, and encompasses their interrelationships in their coexistence and simultaneity - their (relative) order and/or (relative) disorder' (Lefebvre, 1991: 73).

Lefebvre contends that space is not only a product to be used; he suggests that social space is inherently fluid rather than rigid. Further, he observes that repetition in the capitalist city has, for him, 'defeated uniqueness' insofar as the artificial and contrived have driven all 'spontaneity and naturalness' from the fields of architecture and urbanism which should have led to increased levels of diversity. These notions of "spontaneity", "diversity", and the exchange and appropriation of "social space" are all conditions of the street. Miles (1997) contends that the professions of art and architecture align their ideologies to the needs of developers to create "enclaved places". These places are set against the natural evolution of a city in which its dwellers 'determine or at least influence its values and forms' (Miles, 1997: 109). The civic role of public art in providing a voice and a way of expression for citizens is debated in literature (Stevens, 2007); Miles (1997) states that art encourages the use of public places and that making a 'place' for art in the city gives it identity (Miles, 1997: I 17). In Spaces of Hope, by David Harvey (2000) it is proposed that if any political ideology or plan is to work, it must take account of our human qualities. He maintains 
Public Space for Street-Scape Theatrics.

Guerrilla Spatial Tactics and Methods of Urban Hacking in Brisbane, Australia

that, in a utopian sense, we need to learn how to bridge the gap between the personal micro-scale of the body and the macro-scale of the political economy. Through design we must give the individual the right to affect and temporarily personalise their own space within the public domain. This could embellish a renewed right to urban life and the celebration of street-scape theatrics.

The importance of street culture is its ability to reflect societal values on all socioeconomic levels (Gehl \& Gemzoe, 2004). Streets and sidewalks, as juxtaposed to buildings, inherently contribute to the workings of a city through the interconnection of nodes of activity. They serve other purposes than wheeled traffic (Jacobs, 196I). They are the main public places of a city and serve as vital organs for its vibrancy. In many ways the city can only be as good as it streets aesthetically, creatively, and functionally (Jacobs, 196I). Streets are the space where the consciousness of a city can express its self, exchange ideas, and portray a "buzz". It can change the way we think about space because it can promote spontaneous, democratic, and intimate encounters on a human level (Simpson, 2012: 416). This is a level of experience that transcends the city as a consumerist entity. On the streets we can see political protest, social encounters, places of pleasure, places of anxiety, and places of resistance (Simpson, 2012, p4I6). Streets can also be places of performance.

As stated by Cohe and Greenwood (198I: II) 'Street life is a characteristic of cities and towns' this is something that has tended to be undervalued. It can be argued that too much emphasis is placed on the buildings themselves rather than 'the spaces in between then where people interact'. Street-scape theatrics in itself is not a novel idea. It dates back to antiquity, and was highly valued as a form of communication and social interaction (Baird, 2000). Examples of street-scape theatrics are public performances in ancient Rome, renaissance France or modern England (Cohen \& Greenwood, 198I). The tradition of busking, and of human expression in a socio-political context, continues in a modern setting; busking groups are useful in showing 'street tradition as an organic and living thing' (Cohen \& Greenwood, 198I: 18I). However, technological development, to an extent, is the antithesis of musical buskers; this is because music can now be digitally projected into spaces. Music is often used as a commodity, rather than a means of expression and human engagement, often for the purpose of marketing and psychological influences for capitalism. However, the design of urban places and spaces could potentially revitalise the sharing of music in a less consumerist sense and enrich the urban environment.

\section{Methodology}

Busking, as a form of street-scape theatrics, is the focus of this research. Busking, as a definition, will be used to describe musical performance in public space for income and/or pleasure for the artist (other reasons such as exposure, expression, enjoyment, and political motivation may prevail). The desired public space for busking could range from a small to a large area; however, the commonality between all types is a high degree of pedestrian movement and exposure, unless the artist is performing for solitary personal enjoyment. The theoretical analysis has brought to light the importance of Street-scape Theatrics however few sources attempt to discuss this topic in terms of how to design these spaces/places that enhance the city on both a sensory and political level. Therefore 
the research question is how can our sensory experience of the urban environment in Brisbane be enriched through the design for busking?

The research investigates the sensory experience and spatial quality of music in public space, in terms of scale, location and acoustics. The aim of this study is to explore ways to design for freedom of expression and "spatial hacking" through music. It is proposed that the design of public spaces/places could benefit from this way of thinking which attempts to maintain and celebrate the culture and idiosyncrasy of the street and broader urban environment. The methodology for this research is articulated through three different research methods as indicated in Table I.

\begin{tabular}{|c|c|c|}
\hline Method & Description & Aim \\
\hline Case Studies & $\begin{array}{l}\text { A qualitative analysis of public spaces that } \\
\text { have attracted high levels street } \\
\text { entertainment. }\end{array}$ & $\begin{array}{l}\text { I. To study the control over buskers } \\
\text { and street entertainers in } \\
\text { "successful" public spaces }\end{array}$ \\
\hline Interviews & $\begin{array}{l}\text { Multiple interviews with street performers } \\
\text { and musicians. Direct engagement and the } \\
\text { perspectives, experiences, and stories of the } \\
\text { buskers themselves, will provide valuable, and } \\
\text { otherwise un-obtainable, information. } \\
\text { Interview questions primarily relate to ideas } \\
\text { of spatial ownership, personal experience, } \\
\text { territoriality, street performance, unwritten } \\
\text { laws, and social perception. }\end{array}$ & $\begin{array}{l}\text { I. To understand the idiosyncrasies } \\
\text { of Busking to help inform design } \\
\text { decisions } \\
\text { 2. To understand the reasons for } \\
\text { street performance and the various } \\
\text { underlying motivation behind busking } \\
\text { as an activity and form of income }\end{array}$ \\
\hline Observations & $\begin{array}{l}\text { Observations of buskers in the inner city } \\
\text { areas of Brisbane. The types of urban } \\
\text { spaces/places in which these performances } \\
\text { occur will be recorded }\end{array}$ & $\begin{array}{l}\text { I. To identify prominent busking } \\
\text { sites in Brisbane, observe their } \\
\text { characteristics, and draw } \\
\text { relationships to its urban situation } \\
\text { and the spatial qualities that enhance } \\
\text { busking. } \\
2 . \text { To map the acoustic projection of } \\
\text { buskers in the city }\end{array}$ \\
\hline
\end{tabular}

Tab. I. Methodology summary

\section{Research Approach}

When thinking about designing for street-scape theatrics, it is not about contriving a "stage", but harnessing existing conditions favorable for good public interaction. In this way a spontaneous performance can be a product of a well-designed public space, without designing the stage per se. Therefore what elements of a public space contribute to making it a "successful" one? The first and most basic order of a public space is that people attract people. In this sense, a successful public space will have a compounding effect whereby the more people there are using the space, the more people who will want to use the space. Whyte (1980) offers some valuable insight about the general design factors of a successful public space as detailed in table 2 . 
Public Space for Street-Scape Theatrics.

Guerrilla Spatial Tactics and Methods of Urban Hacking in Brisbane, Australia

\begin{tabular}{|c|c|}
\hline Design Consideration & Description \\
\hline Sit-able Area & $\begin{array}{l}\text { Hospitable but come in a variety of combinations to give the sitter choice. } \\
\text { When considered on a human level, miscellany is more attractive than } \\
\text { regulation }\end{array}$ \\
\hline "Triangulation" & $\begin{array}{l}\text { Any element such as a sculpture, piece of art, or performance that can bring } \\
\text { people together into a critical mass. This could be anything that engages people } \\
\text { and stimulates interaction, contribution to the sociality of the space (Whyte, } \\
\text { 1980). }\end{array}$ \\
\hline $\begin{array}{l}\text { Connection with } \\
\text { Street }\end{array}$ & $\begin{array}{l}\text { A good public space has an open and lucid relationship to the street which is } \\
\text { essentially 'the river of life for a city'. A public space is to be a landmark, } \\
\text { something people walk past, point to, discuss, and orientate themselves }\end{array}$ \\
\hline Environmental & $\begin{array}{l}\text { Sun - Highly favourable in winter, natural light in general is important. Water - } \\
\text { stimulates the senses through sound, look, and feel. Water - If present it } \\
\text { should not be blocked off from interaction and use. Trees - shade and } \\
\text { presence of natural environment }\end{array}$ \\
\hline Scale & $\begin{array}{l}\text { If the space is over scale, it fails to bring together a critical mass of people } \\
\text { because people feel vulnerable in the middle of large public spaces }\end{array}$ \\
\hline Amenities & Toilets, Food/Refreshments \\
\hline Safety & To what extent does the public feel comfortable or vulnerable in a space \\
\hline Optional Activities & In public spaces, optional activities are the most prominent (see figure 6) \\
\hline
\end{tabular}

Tab. 2: General Design Factors for “successful” Public Space as set out by Whyte (1980)

The research introduces a theoretical approach based on the work of Whyte (1980), Foth (20II), MacKenzie (2009) and Guaralda (20I3). As detailed in Table 3, five paramenters are taken in considetion in discussing selected case studies. The socio-economic context is evaluated in order to contextualise the space analysed, understand its history, its uses and its general design. Busking is the main activity observed and evaluated in terms of its value as a placemaking exercise aimed to foster social interaction (Gehl, 1987). Activities in public spaces are often subject to a specific set of rules, guidelines and prescriptions. Governance of space has been investigated to understand the institutional framework within which buskers might have to operate. Physical layouts and spatial configurations are addressed to understand the actual design of a case, while soundscapes are evaluated to contextualise busking activity in the broader urban landscape.

\begin{tabular}{|c|c|c|}
\hline $\begin{array}{l}\text { Theoretical/Political } \\
\text { Consideration }\end{array}$ & Description & Method of Investigation \\
\hline Socio-economic context & $\begin{array}{l}\text { General information about the space } \\
\text { (History, Commercial/public/private) }\end{array}$ & Case Studies \\
\hline Busking & Provisions/Value & $\begin{array}{l}\text { Case Studies, Interviews, } \\
\text { Observations }\end{array}$ \\
\hline Control/Governance & $\begin{array}{l}\text { Levels of restriction over the way the } \\
\text { space is used with regards to authority, } \\
\text { permits, and sound levels. }\end{array}$ & Case studies, Interviews \\
\hline Spatial Characteristics & $\begin{array}{l}\text { The spatial elements of popular busking } \\
\text { locations }\end{array}$ & Observations, Interviews \\
\hline Social Preconceptions & Societal views about buskers & Interviews \\
\hline Sound projection & Audibility within City & Observations, Interviews \\
\hline
\end{tabular}

Tab. 3. Research approach 
This approach will be used to draw conclusions about how 'the right to the city' can be enhanced in a socially equitable way for the Brisbane CBD. Social Equity is intended as the idea that 'all social values - liberty and opportunity, income and wealth, and the basis of self-respect - are to be distributed equally unless an unequal distribution of any, or all, of these values is to everyone's advantage' (Ralws, 1972: 22 cited in MacKenzie, 2009: 76).

\section{Case Studies}

Different cities deal with busking in different ways. Melbourne and Brisbane in Australia have been analysed in terms of how their government regulates street-scape theatrics and the unstructured use of public places. Comparing policies and official documents provide an idea of how busking is not always perceived as problematic in the capitalist city (Brisbane City Council, 2012; City of Melbourne, 200I; Project for Public Spaces, 20I2). In Melbourne, buskers have to pass an audition to perform in Bourke Street Mall as 'live performances increase' (Gardiner, 20 I I). According to the City of Melbourne (20I I), a professional busker is a 'performer who busks as their main source of income, has a repertoire that would enable them to perform for at least 30 minutes without repeating a song, and has a website, YouTube, Facebook or other profile'. Despite an apparent high level of opposition to the plans to audition buskers, the resultant decision by the Melbourne council was that permit allocation will come under the scrutiny of a panel of council officials and an experienced busker. According to the city councillors, the Bourke Street buskers are required to demonstrate a higher than average level of accomplishment and a 'unique quality, subtle or dramatic, that gives them an interesting edge and makes them unlike other performers' (cited in Gardiner, 20 I I). Within the rest of the city, buskers must be judged only to make sure they are safe and not offensive. According to the City of Melbourne's Street Activity Policy (20II), it recognises the valuable contribution that street entertainment makes to the 'life and vitality of a city' and states that artistic and cultural life is integral to Melbourne as a creative city. Thus the city encourages performers from all 'backgrounds, abilities and through different mediums to showcase their craft' (City of Melbourne, 20II). The control measures have been introduced on the basis of providing a structured framework as to minimise the complaints, criticism, and other issues relating to the ambience and amenity of the city's public realm.

Queen Street Mall, is a commercial public space in Brisbane, Australia, and has traditionally been considered as the cornerstone of retail and fashion in Brisbane CBD. Queen St claims to attract 26 million visitors a year and contains over 700 retailers and is thus highly commercialised (bnecity, 2012). Due to its high level of pedestrian traffic, Queen Street Mall has become a popular place for street entertainers and buskers alike. Akin to Bourke Street in Melbourne, Queen Street Mall also requires aspiring buskers to attain a licence for the privilege of using the space. According to the Brisbane City Council, busking licences are free; however performers are required to submit an application prior to attending an audition. Unlike Bourke Street, there are not any council restrictions on the general amount of buskers in the mall at any point of time. There are also no provisions for the length of performance and depth of performance material. A notable audition rule 
Public Space for Street-Scape Theatrics.

Guerrilla Spatial Tactics and Methods of Urban Hacking in Brisbane, Australia

is concerned with the neat appearance of the busker where preference will be given to buskers who are dressed appropriately for the act (Brisbane City Council, 20I2). In both cases performers are requested to possess a permit to perform in central locations; busking is recognised as an important activity to activate public spaces and make them a vibrant component of the urban life. Street performers and buskers will generally set up where a high level of movement already exists. However there is also an effect where buskers draw the public to a space that they otherwise would not have visited. This is particularly exemplified by world renowned public spaces such as Las Ramblas in Barcelona (Project for Public Spaces, 2012). The artful street culture creates an attractive and diverse experience for pedestrians and as a result of its social quality, it is described as the "emotional hub" of the city. This is a key factor for its high usage and for this reason Las Ramblas has become known as an international cornerstone of street art and performance. This effect is also noted in Bourke Street where the existence of cultural exchange brings about its high level of use. As discovered through the interview process, this is a dialectic effect which is not present in Brisbane because the provisions in the CBD do not enhance the notion of street-scape theatrics

The mechanics of the permits in central locations align with the image a city wants to project of itself. The quality of buskers is assessed in order to create a pleasant environment for the majority of city dwellers. While the selection process provides access to the urban stage for a variety of artists, on the other hand the permit structure has an impact on the right of citizens to access and express them in the public realm.

\section{Interviews}

With regards to permits and authority, all five interviewees (Brisbane based) claimed that their negative run-ins with authority are very minimal to non-existent. Therefore, the simple act of exercising common sense, without being publicly obnoxious will be generally accepted by authorities. Interviewee I claimed that he busked across Australia as mode of transience without a permit and recorded no negative run-ins with authorities. The general view is that there has to be some level of competency when providing entertainment in a public space because a performer is using it in "bigger ways" than the general public. Therefore there is a responsibility and onus that you are adding to the urban experience, not detracting from it. Further, there are musicians who busk as a large source of their livelihood as a refined art form. As stated by one interviewee, 'For someone to come out and be belligerent, and not have perfected their art, it's annoying'. Another prevalent point was that without permits, malls run the risk of becoming saturated with buskers thus desensitizing the public. Therefore, permits where seen as a good measure. With regards to Queen Street Mall, you have to attain a permit for the mall and there's no amplified busking. However, according to one of the interviewees (Interviewee 5), Melbourne and all other cities authorities allow amplified busking. These codes of written and unwritten laws relate to the idea of equity in a public space. People should have the right to express themselves but the concept of "greatest happiness for the greatest number" principle is an underpinning belief (Hutcheson, 1725). Thus quality control is a good notion for commercial public space but only if the power structures of the space meet halfway with the street performers to enhance the 
experience (Chambers, 20I3). None of the interviewees actually busked in Queen Street Mall because the sound gets lost for acoustic performers and amplified busking is not authorised. Therefore the commonality was to busk outside of the permit required zones and in places where sound dissipation was not as prevalent. If Queen Street Mall was to celebrate "street-scape theatrics" some provisions in terms of a more egalitarian distribution of spatial ownership would have to be made. This notion of spatial ownership can become quite complex especially regarding a commercial space such as Queen Street Mall. This can come in two levels, spatial ownership on a societal level (permits), or between competing buskers (Respect/Unwritten law).

A commonality between all buskers is that there is a strategy and relationship between the location and time to maximise exposure (Kushner \& Brooks, 2000). Therefore these locations would change throughout the day. Buskers often get more interest at night because people are out to be entertained whereas people generally have an agenda throughout the day. However, at an event such as a market place, the public tend to show higher interest. This would be due to a lower pressure of time. Also, certain areas where people are spilling out going between clubs, or having food provide good spaces for busking. Therefore, when considering a desirable location, it is important to think why the public occupy that space. Interviewee 2 made that comment that train stations were desirable because people were already shuffling through change in their hands. They would often see a busker and throw in some spare change. An interesting notion about busking is that it affects the space in ways which the public would not expect and therefore brings about a new value to the way the space is being experienced and manipulated. There exists the potential to make the public think or feel differently. An interesting statement was made by an interviewee regarding the ways in which the public interacted with his music:

Everyone would walk to the same beat, and I would actually find myself playing to that beat. But I found that if I played counter to that beat or changed it up it made people notice more. I thought that was pretty fascinating... Before $5 \mathrm{pm}$ and after $6 \mathrm{pm}$ so in that time it was just too intense, they couldn't see anything in front of them. People would need to be able to see you from at least 10 - 15 metres away and know that you were there so that they would make a conscious decision about if they were going to respond or not. (Interviewee 3)

Societal preconceptions and reactions play a major role in the notion of spatial ownership for a performer. To an extent, the more experience you have with busking, the more comfortable the performer will feel in public space. As stated by one of the interviewees, "I had been doing it for a long time I just felt like I was in my own space". The prevalent question in relation to social acceptance is whether the space being culturally enhanced or depredated. The general societal reaction towards busking is mostly positive, adopting a 'more music the better' attitude. However, playing in Melbourne was seen as preferable to playing in Brisbane indicating that Melbourne is a more culturally advanced city and spaces are more socially dynamic. It was also noted that there is a notion that busking in another city can be preferable to busking in your own city. In the process of busking, you can become a "Chameleon" insofar as an anonymous persona, however some buskers find it hard to adjust in your own city or places of prior associations. This indicates that there 
Public Space for Street-Scape Theatrics.

Guerrilla Spatial Tactics and Methods of Urban Hacking in Brisbane, Australia

are negative connotations that are associated with busking such as desperation or homelessness. However, interviewee 2 had the contrary view and used busking as way of socializing. He stated:

If you, in your mind think that busking is a form of begging then you might feel a sense of shame from that but I didn't, I felt like I was just being a street performer.

Predictably it was found that financial motivation is always a present factor for busking. The location for where a busker sets up is called a "pitch". However, most of the interviewees stated that the "pitch" is not the only factor and often not even the primary motivation. It was the combination between being able to express one's self and also achieve some financial gain that drives a musician to play in public space. The experience, promotion and practice were often equally as important as the finance.

Interviewee 2 claimed that he would make about $\$ 10$ per hour and thus it was not enough to consider a career pursuit... the best nights weren't the nights that we thought we made $a$ lot of money, it was the nights where there was a group... dancing around us, singing along to the cover songs... people would come from standing in line at a club or bar, and join along in the atmosphere. And it wasn't about the money... (Interviewee I)

Through the interview process key points of importance emerged.

- It can transpose the space from a means of going from $A$ to $B$ to a social space where interaction between people on a creative level can be valued.

- The cultural exchange is not predefined but can be surprising, irregular or make a pedestrian feel, see or hear something that they weren't expecting.

- Busking is inherently a mutual experience. The entertainment is offered before the payment, rather than a traditional performer who has a set fee agreed on before the performance. In this way the public will only pay if the art or circumstances are considered worthy of that payment.

- The general public can exercise a preconception of buskers as people begging for money, or engaged with low class activity.

- Permits are generally an accepted measure of quality control in busy commercial spaces.

\section{Observations and Mapping}

Building on the findings from the interviews, observations have been made in three locations within Brisbane CBD; preliminary data collections have allowed us to identify the main sites used by buskers, as summarised in Figure I. Detailed observations of them be conducted in three locations, one in Queen Street Mall, requiring the busker to hold a permit, and two in areas just outside the Mall. Spatial and environmental qualities have been surveyed. Sounds dispersion has also been measured to evaluate the potential of each site in providing good exposure to buskers. 


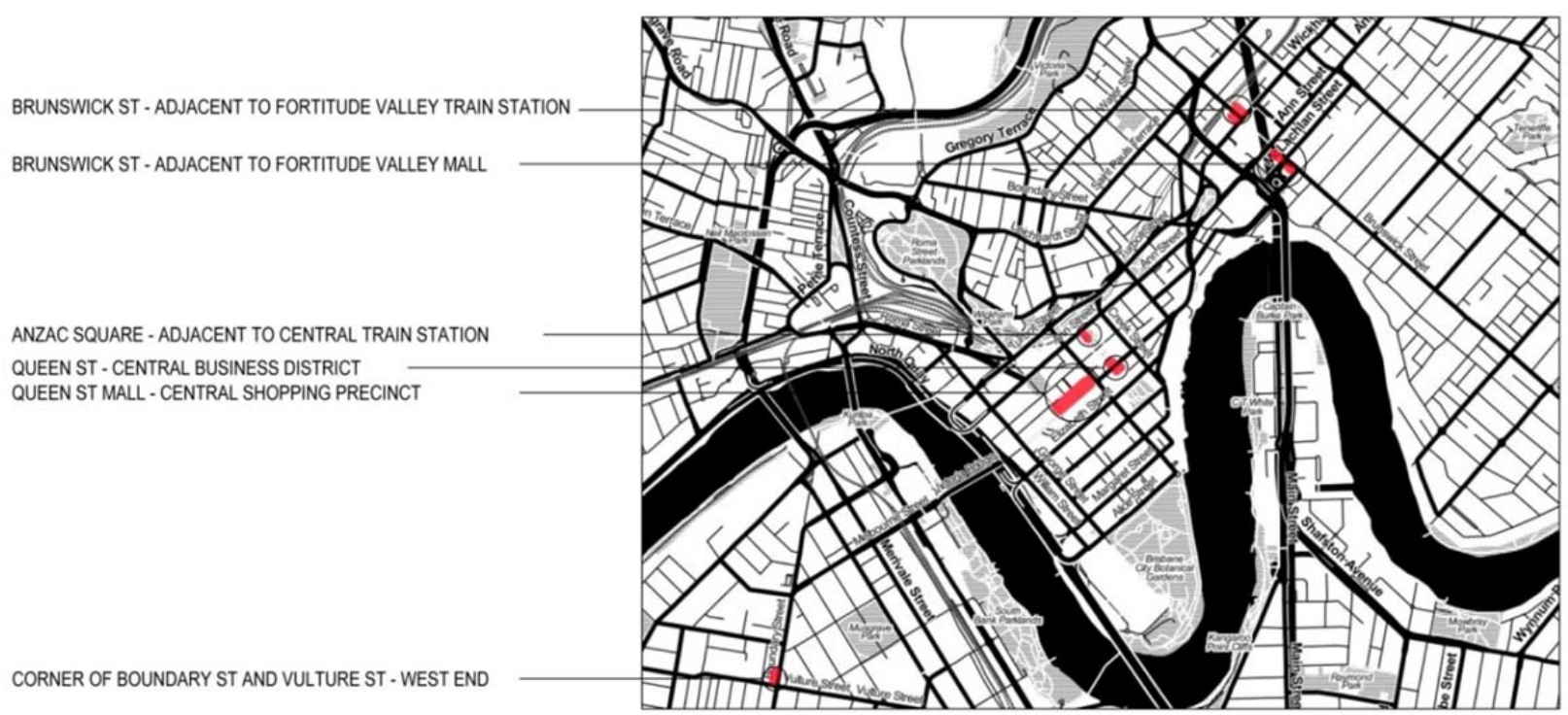

Fig. I. The preliminary mapping of busking sites in Brisbane

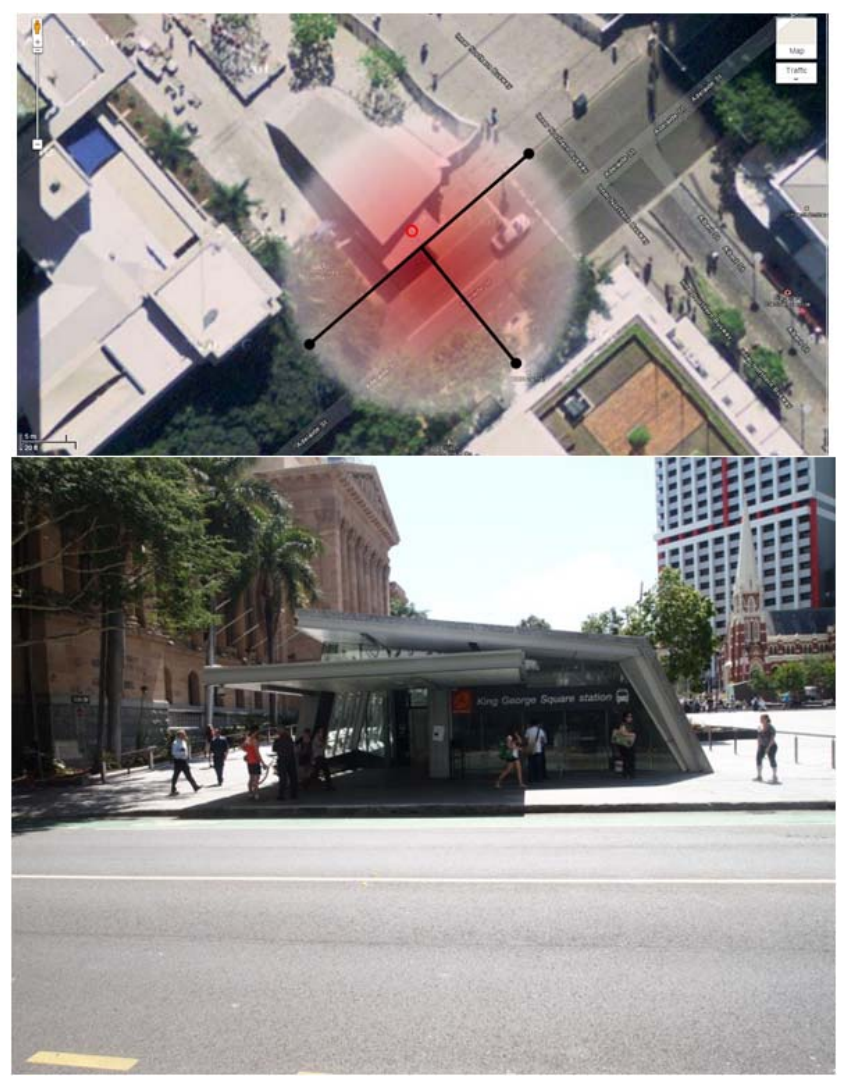

Fig. 2-3. Acoustic busking sound projection example I (base - Google Maps) 


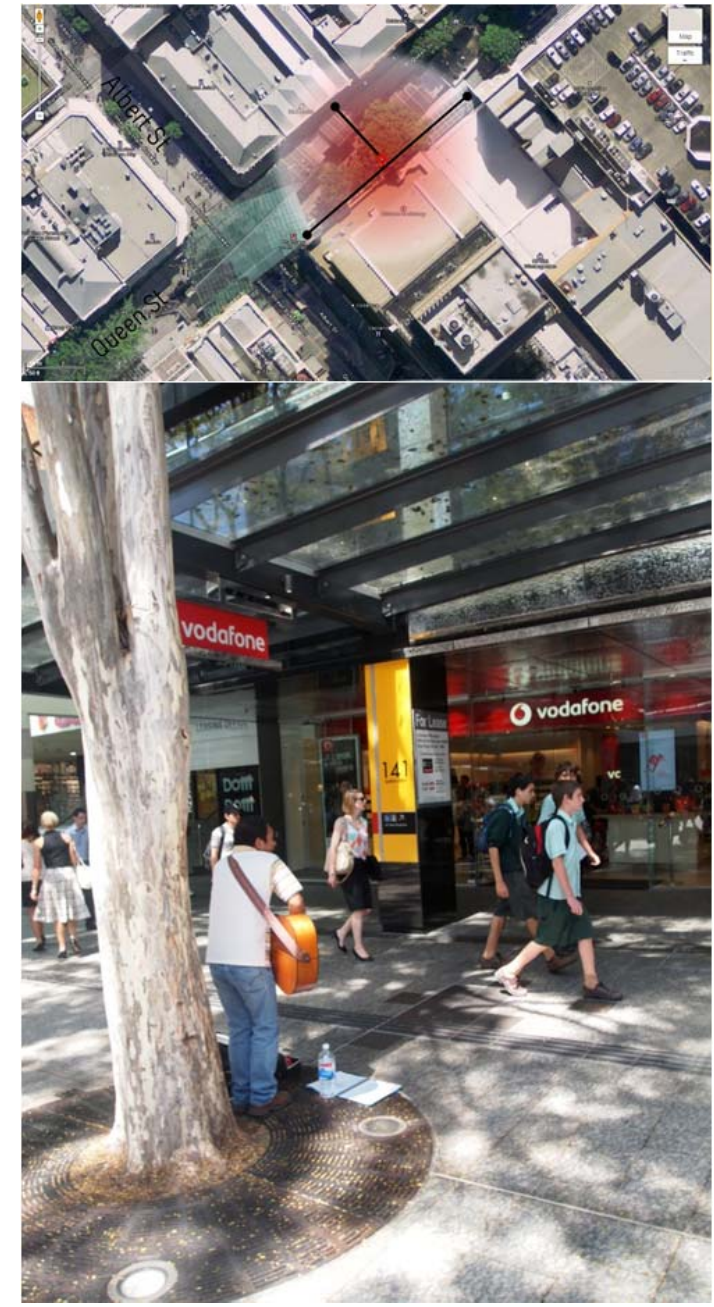

Fig. 4-5. Acoustic busking sound projection example 2 (base - Google Maps)

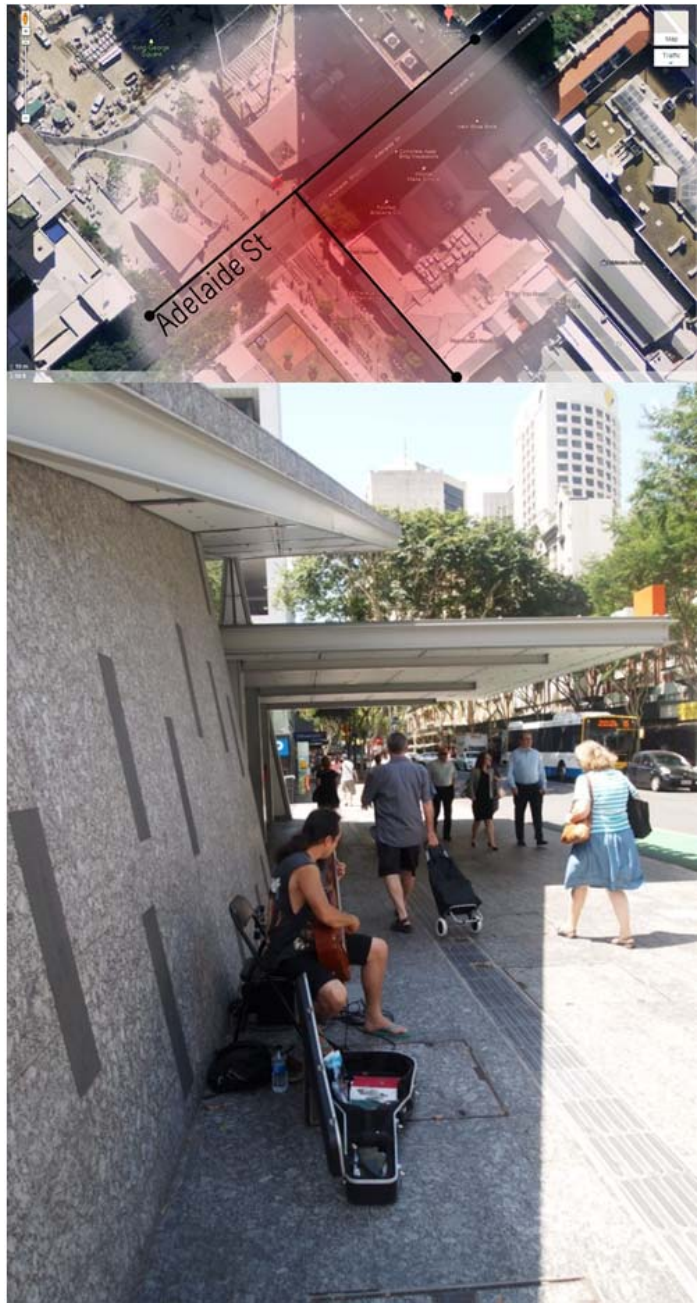

Fig. 6-7. Amplified busking sound projection comparative example (base - Google Maps)

\section{Discussion}

Through the literature review, interview analysis, and prior observations it has been identified that busking provides a valuable contribution to public space without compromising the individual liberties of the overall public. The sharing of music on the street induces the Lefebvrian notion of having a 'right to the city' as the performer can temporarily affect the sensory experience of public space and connect with people on a humanistic level. With this in mind the right for the public to express themselves through music in the Brisbane CBD could be improved by making the following provisions.

I. Allowing amplified sound in the city with appropriate sound levels and permits would be an appropriate measure for Queen Street in celebrating street-scape theatrics. As noted by the prior observations, amplified busking in Brisbane CBD achieves a sound projection of up to four times the radius of an acoustic busker. This is important for buskers in the city, as competing with ambient noise without amplification is difficult, and has been identified as the most difficult barrier to their art form. 
2. In a prominent section of Queen Street mall there exists numerous speakers positioned above the shop fronts projecting commercial music into the space. Not only does the Brisbane City Council disallow amplified busking in the mall, these speakers in the area outlined by figure $7 \& 8$ nullify opportunity for busking in this area of Queen Street This is at a place where people are not only passing by they are sitting and socialising at the Pig and Whistle Hotel. To nullify this ideal location for busking and street entertainment seems unnecessary being that Queen Street openly endorses street entertainment. As a notion, this reduces the public's 'right to the city' by way of art. As Interviewee 5 stated, this is not a notion that is experienced in Melbourne. He contends that 'I'm registered in the Burke St mall and because of the busking there they don't have any commercial music playing...'
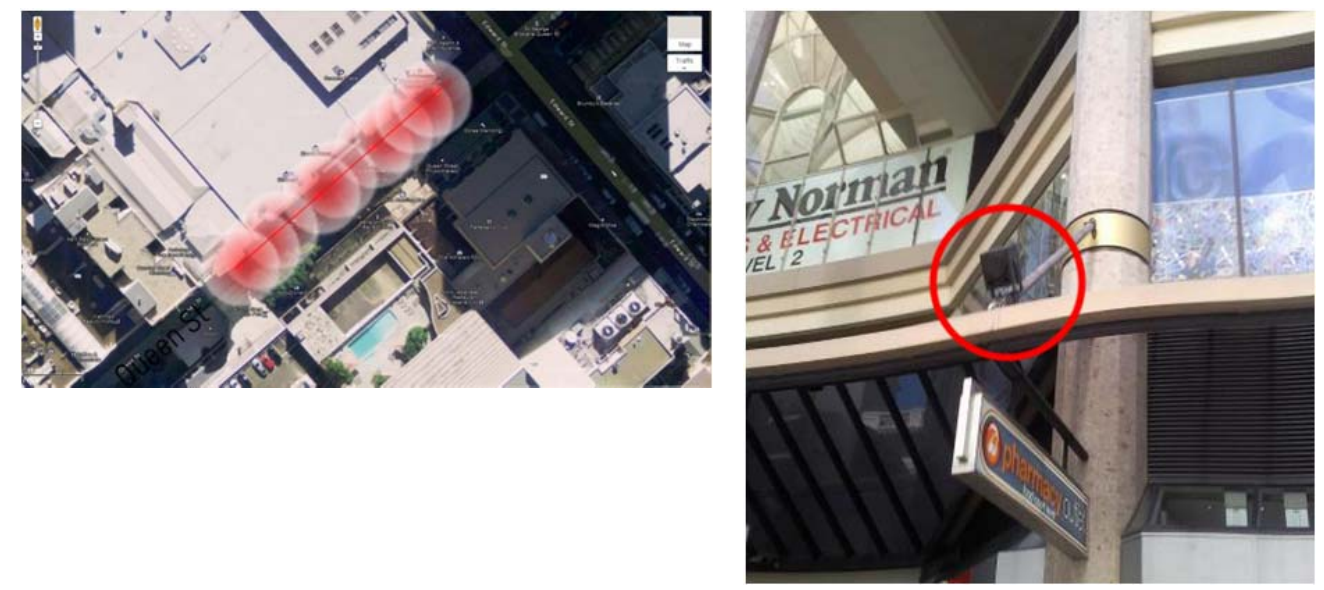

Fig. 7-8. Nullification of Busking in favourable public spaces

3. The third recommendation is the designation of discrete spots within a public space that facilitates buskers. In Melbourne the number and locations of buskers are regulated and this generally contributes to an overall engaging experience for city users, who are not overwhelmed by different auditory stimuli. As commented by Interviewee 5 , an experienced busker, 'People don't really take busking as an important part of designing the city but now it's starting to take shape... Melbourne has accommodated designated spots to busk, everywhere in Melbourne...' Therefore, if designated busking spots were provided in Queen Street mall along with the aforementioned provisions, the experience of public space could be enhanced with adequate quality control measures being taken. As stated by an interviewee involved in the audition and licensing process for buskers in Brisbane, busking has a positive impact on public space. 'IfI see music anywhere, l'll stop and have a look and listen. And that's what the people do, people wandering around shopping' he states. Ideally, these busking spots could not only be designated, but designed into the leftover space within the urban fabric at specific locations that are desirable to buskers. These could be in the form of busking "spots" that could allow buskers to freely manipulate the conditions of the set area to improve the experience both functionally and aesthetically:

- Improve acoustic projection

- Very basic amenities including a power source and seating

- Incorporate miscellaneous seating arrangements if appropriate 
Public Space for Street-Scape Theatrics.

Guerrilla Spatial Tactics and Methods of Urban Hacking in Brisbane, Australia

- Aesthetic recognition of the value of street-scape theatrics

- These could serve a multitude of functions beyond busking that could extend into rallies and street forums

- Retain priced permits and auditions, but the money generated goes towards funding these provisions

Figure 9-II depict potential for designated spots to be incorporated into leftover urban fabric in locations conducive to busking. The design of these places is intended to evolve as its users refine the space.
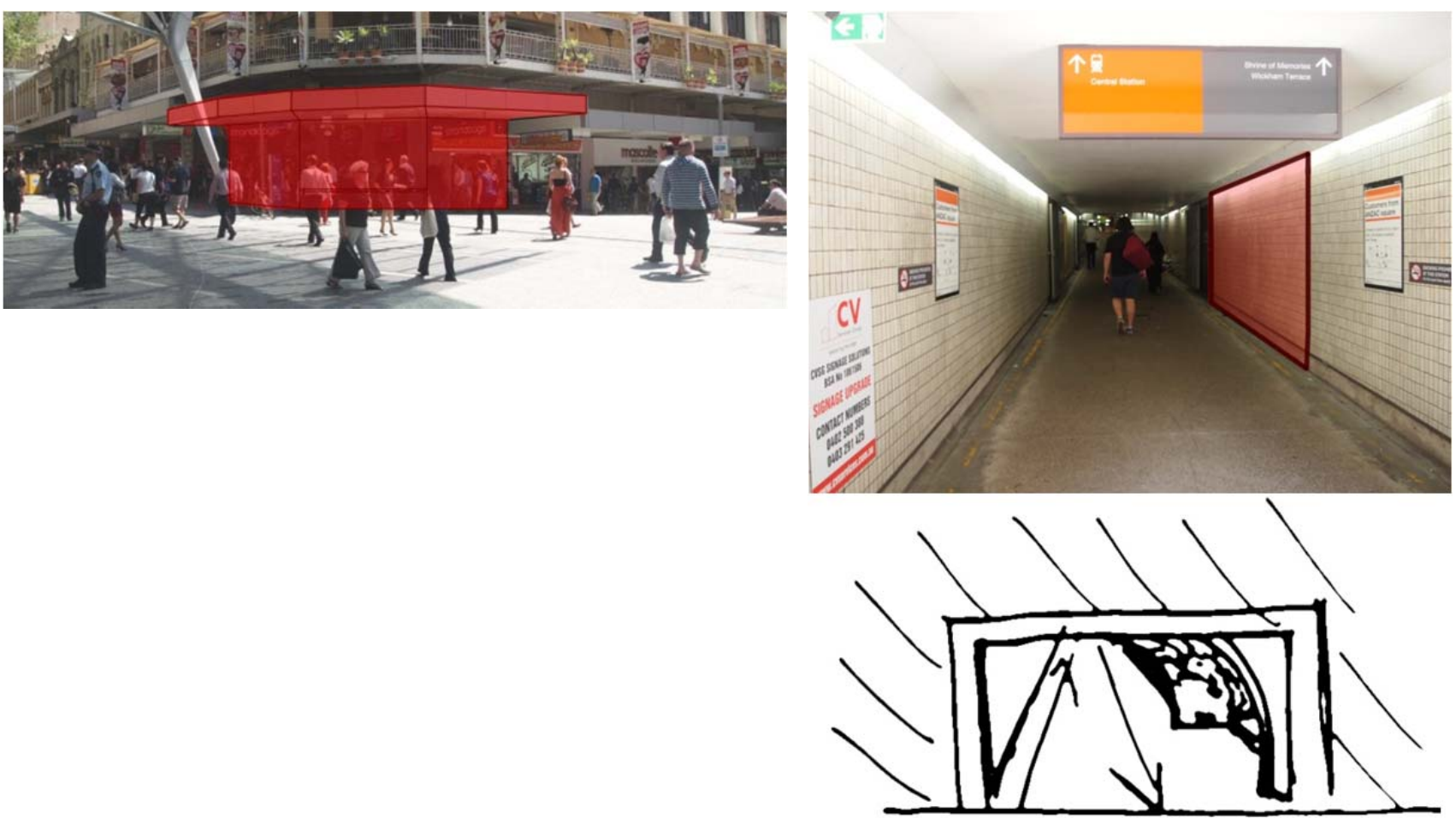

Fig. 9-10-II. Potential busking spots in Brisbane CBD.

\section{Conclusion}

The research has provided evidence that there are ways in which the Brisbane CBD can be enriched through an increased appreciation for street performance. Street culture is a notion that already exists in the Brisbane city but is repressed by over governance of public space. It is proposed that incorporating these suggestions into the design of public space both physically and politically would enhance the Lefebvrian idea of maintaining a 'right to the city'. There lies the potential to enhance the sensory experience of our public space. This leads to a determination of the practicality of designing busking into the leftover urban fabric and critical thought to the way the city is allowed to express itself in a sensory and experiential way.

Some limitations to this research have been prevalent. The first limitation is time. This research was conducted over a period of three months, a relatively short period of time 
for a complex issue. Therefore, the project contributes to a body of knowledge that aims to surface the idea of design for street-scape theatrics. Is not expected that this particular research would have immediate societal consequences that could involve redefining the way in which planning regulations may be developed or acted upon. However, what has been achieved is a body of ideas that demonstrates how public spaces can be enriched through retracting over-governance and over-organisation and giving the public the right to express themselves in public spaces in a way that does not compromise the individual liberties of others. It is crucial that the notion of ensuring a 'right to the city' by way of art is always prevalent in our public space. This can bridge the gap between the micro scale of the body and the macro of the political economy through allowing freedom of expression and thus celebrating the idiosyncratic nature of the city.

\section{References}

Agiurre, A. (2007). Urban Space. In G. Ritzer (Ed.), Blackwell Encyclopaedia of Sociology. Malden, Mass, Oxford: Blackwell. Retrieved from http://www.blackwellreference.com/public/tocnode?id=g978I405I2433I_yr20I2_chunk_g978I $40512433127 \mathrm{ss}$ I- 18

The American Heritage Dictionary of the English Language, Fourth Edition. (2009). Boston, MA: Houghton Mifflin Harcourt.

Baird, S. (2000). The History and Cultural Impact of Street Performing in America. In B. Franklin (Ed.), Street Performers and Buskers Advocates.

Bnecity (20I2). Queen Street Mall. http://www.bnecity.com.au/Storelnformation.aspx?id=35I2 (accessed 27th August 20I2)

Borden, I. (200 Ia). Skateboarders are essential for our cities Retrieved March I2th, 20I2, from http://www.independent.co.uk/opinion/commentators/skateboarders-are-essential-for-ourcities-69380I.html

Borden, I. (200 Ib). Skateboarding, space and the city: architecture and the body. New York: Berg.

Brisbane City Council. (2012). Busking Licences Retrieved 27th October 2012, from http://www.brisbane.qld.gov.au/laws-permits/laws-and-permits-for-businesses/mallsmanagement-markets/busking-licences/index.ht $\mathrm{m}$

Chambers, C. M. (20I3). Busking and the Performance of Generosity: A Political Economy of the Spiritual Gift. Performing Religion in Public, 256.

City of Melbourne. (200I). Bourke Street Mall busking permit Retrieved 2th November 20I2, from https://www.melbourne.vic.gov.au/enterprisemelbourne/industries/design/StreetEntertainment/P ages/BourkeStreetMallPermit.aspx

Cohen, D., \& Greenwood, B. (I98I). The buskers: a history of street entertainment. Newton Abbot: David \& Charles.

Coleman, N. (2013). Utopian Prospect of Henri Lefebvre. Space and Culture, 16(3), 349-363.

Dangschat, J. S. (2009). Space matters - Marginalization and its places. International Journal of Urban and Regional Research, 33(3), 835-840.

Deslandes, A. (20I3). Exemplary amateurism: Thoughts on DIY urbanism. Cultural Studies Review, $19(1), 216-227$.

Foth, M. (20I I). From social butterfly to engaged citizen: urban informatics, social media, ubiquitous computing, and mobile technology to support citizen engagement. Cambridge, Mass: MIT Press.

Gardiner, A. (20II). Bourke St buskers risk being banned. http://www.heraldsun.com.au/news/victoria/bourke-st-buskers-risk-being-banned/storye6frf7kx-1226017347/27 (Accessed 27th October 20I2) 
Public Space for Street-Scape Theatrics.

Guerrilla Spatial Tactics and Methods of Urban Hacking in Brisbane, Australia

Gehl, J. (1987). Life between buildings: using public space, Reinhold Pub.Co.

Gehl, J. (2010). Cities for People. Washington DC: Island Press.

Gehl, J., \& Gemzoe, L. (2004). Public Spaces Public Life. Copenhagen, The Danish Architectural Press \& The Royal Danish Academy of Fine Arts School of Architcture Publishers.

Goldsmith, M. (1980). Politics, Planning and the City. GB: Routledge Ltd.

Guaralda, M. (20I3). Eye on the Street? Sensory Experience in Public Places. In_Bo Ricerche e progetti per il territorio, la cittá e l'architettura, 4(I), 7I-80. doi:I0.6092/issn.2036-1602/37II

Harvey, D. (2012). Rebel Cities: From the Right to the City to the Urban Revolution, Verso Books.

Hays, K. M. (1998). Architecture theory since 1968. Cambridge, Mass: The MIT Press.

Heathcott, J. (20I2). Planning note: Pruitt-igoe and the critique of public housing. Journal of the American Planning Association, 78(4), 450-45I.

Holt-Damant, K., Guaralda, M., Gomez, T., \& Miriam, N., Cindy. (2013). Urban jungle : making cities healthy places for Australians with neurodiversity. Paper presented at the 6th Making Cities Liveable Conference, in Conjunction with the Sustainable Transformation Conference, Melbourne, St Kilda.

Hou, J. (2010). Insurgent Public Space: DIY Urbanism and the Remaking of Contemporary Cities. GB: Taylor \& Francis Ltd - M.U.A.

Hutcheson, F. (I725). Inquiry concerning Moral Good and Evil.

Jacobs, J. (Ed.). (196I). The death and life of great American cities. New York: Vintage Books.

Jubany, H. L. (20I2). Design Intelligence. The Social Responsibility of Architects Retrieved March I5th, 20 I2, from http://www.di.net/articles/archive/the_social_responsibility_architects/

Kushner, R., \& Brooks, A. (2000). The One-Man Band by the Quick Lunch Stand: Modeling Audience Response to Street Performance. Journal of Cultural Economics, 24(I), 65-77.

Lefebvre, H., \& Nicholson-Smith, D. (199I). The production of space. Oxford: Blackwell.

MacKenzie, I. (2009). Politics: Key Concepts in Philosophy. London: Continuum.

Mensch, J. (2007). Public Space. Continental Philosophy Review, 40(I), 3I-47.

Miles, M. (1997). Art, space and the city: public art and urban futures. New York; London: Routledge.

Orom, H., \& Cervone, D. (2009). Personality dynamics, meaning, and idiosyncrasy: Identifying crosssituational coherence by assessing personality architecture. Journal of Research in Personality, 43(2), 228-240.

Orwell, G. (1946). Animal farm. New York, Book: Harcourt, Brace \& World.

Power, N. (20I0). Humanism. In M. Bevir (Ed.), Encyclopedia of Political Theory. Thousand Oaks, CA: SAGE.

Project for Public Spaces. (20I2). Las Ramblas Retrieved 7th August 20I2, from http://www.pps.org/great_public_spaces/one?public_place_id=59

Simpson, P. (2012). Apprehending everyday rhythms: rhythmanalysis, time-lapse photography, and the space-times of street performance. Cultural Geographies, 19(4), 423-445.

Stevens, Q. (2007). The ludic city: exploring the potential of public spaces. New York: Routledge.

Torgovnik, E. (1990). The politics of urban planning policy. Jerusalem. Lanham, Md: University Press of America.

Whyte, W. H. (1980). The social life of small urban spaces. Washington, D. C.: Conservation Foundation.

Wilkins, C. L. (2007). The Aesthetics of Equity. Notes on Race, Space, Architecture, and Music. Minneapolis: University of Minnesota Press. 